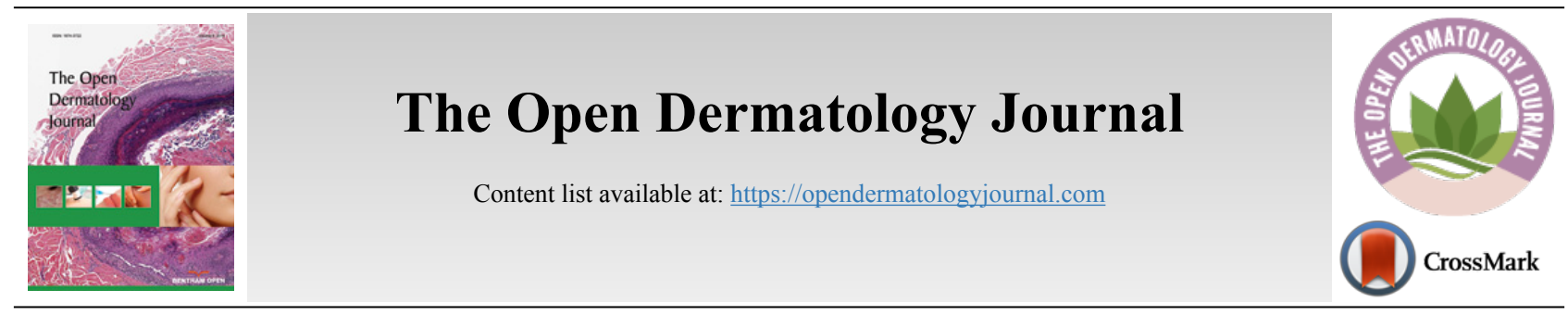

RESEARCH ARTICLE

\title{
An Ayurvedic Based Dermal Treatment for Skin Sanitization
}

\author{
Pranay Wal ${ }^{1, *}$, Ankita Wal ${ }^{1}$, Rashmi Saxena Pal ${ }^{1}$, Yogendra Pal $^{1}$ and Nikita Saraswat ${ }^{1}$ \\ ${ }^{1}$ Institute of Pharmacy, Pranveer Singh Institute of Technology, Kanpur, Uttar Pradesh, India
}

\begin{abstract}
:
Background:

Due to the prevailing coronavirus crisis, the use of sanitizers has become an urgent need of today to take preventive care as we step out for various reasons. Many brands and varieties of sanitizers are available in the market today.

Objective:

The present study has been undertaken to develop and analyse the effects of an Ayurvedic preparation to overcome all the ill effects exerted on the skin by the chemical-based sanitizers. As there are very bad long-lasting effects on skin after continuous use of synthetically derived sanitizers. This pandemic situation has forced all of us for using sanitizers at least 10 times a day, especially for children and the Geriatric population.

\section{Material and Methods:}

Formulation was developed with the help of natural ingredients and then it was evaluated on the safety and efficacy standards to make sure about the credibility of the designed preparation. The benefits of using this formulation were observed during the health camps organised by Diabport health care at various parks in Kanpur. The texture of the skin was improved and apart from this. This was assessed with the help of a questionnaire (KAP) which was developed and validated.

Results:

The herbal based sanitizer, derived from Ayurvedic principles, was found to be quite effective against germs, microbes and it was beneficial for the care of hands also. Hands were soft and irritation free when the herbal sanitizers were applied for optimum time. We have observed that those patients who have history of high sugar level are more prone of developing rashes due to excessive usage of sanitizers. Diabetic dermopathy was also relieved. The population which used this formulation showed sign of improvement in both the texture of skin as well as decreased number of rashes.

Conclusion:

Herbal-based sanitizers are the need of the hour to combat the danger of corona, keeping the hands mild and soft. More focus on them should be encouraged on a large scale.
\end{abstract}

Keywords: Herbal, Ayurveda, Sanitizer, COVID, Anti-microbial, Skin.

\begin{tabular}{|l|l|l|l|}
\hline Article History & Received: January 13,2021 & Revised: April 1, 2021 & Accepted: April 17, 2021 \\
\hline
\end{tabular}

\section{INTRODUCTION}

Due to the prevailing coronavirus crisis throughout the world, hand sanitizer dispensers and wipes are easily accessible at grocery stores, malls, offices, etc. Keeping our hands clean helps to keep check on the spread of disease and people are nowadays using hand sanitizer regulary [1]. Since it has to be applied many times a day, so the FDA has decided that the

\footnotetext{
* Address correspondence to this author at the Institute of Pharmacy, Pranveer Singh Institute of Technology, Kanpur, Uttar Pradesh, India; Tel: 9795967709; E-mail: drpranaywal@gmail.com
}

companies making hand sanitizers need to ensure more that those chemicals are safe for that exposure level mainly for pregnant women, old age and children. So it is essential to keep in mind the safety prospects related to health hazards as well [2]. Washing hands regulary with soap is far superior as compared to using hand sanitizer. Soap removes dirt, germs and oil from hands to give a better and hygienic cleansing. Soap and water are beneficial than hand sanitizers in removing certain kinds of germs, like novo virus and clostridium difficile [3]. Soap also removes pesticides and other chemical based residues left behind on hands [4]. Sanitizer works primarily 
through the power of alcohol. Alcohol can kill many types of bacteria and viruses by destroying their outermost layer [5]. Knowing that washing hands is way better as compared with sanitizers, but as it is not possible every time and in this prevailing arena of pandemic, no option remains apart from using sanitizers [6]. After analysing the sanitizers available and the effects produced by them, it has become necessary to formulate a sanitizer derived from natural ingredients, carrying full capacity to kill the Coronavirus after leaving hands soft and moisturized [7, 8]. Hand washing results in cracked skin that provides an entry for germs [9 - 11]. Hand sanitizers were also effective in reducing gastrointestinal disorders, respiratory and skin infections [12]. Some claimed hand sanitizers are not effective in decreasing microbial load on hands $[13,14]$.

Here are some of the dangers posed by overusing chemical-based hand sanitizers.

- These chemicals may cause dermatitis on a regular basis. With natural sanitizers, these issues are removed.

- FDA advises consumers not to use any methanol hand sanitizer $[15,16]$.

- People may not properly wipe off hand sanitizer before it has dried.

- Some are less effective as their alcohol concentrations are lower.

- The alcohol content can cause skin sensitivity.

- It can cause redness on hands.

- Hand sanitizers can also cause dryness and peeling of upper skin layers, as shown in Fig. (1) [17, 18].

- Hands become more sensitive to UV light This means that susceptibility for getting sunburn on hands increases. This side effect occurs as alcohol in the hand sanitizer dries skin, causing it to have thinner layers, allowing the harmful rays of Sun to penetrate deeper layer of skin of hands [19].

- Some hand sanitizers contain triclosan instead of alcohol. Triclosan is an anti-bacterial and anti-fungal agents used as an essential for soaps and cleaning agents. It causes allergic reactions on entering the bloodstream [20, 21].

- Decreased effectiveness can cause bacteria and germs to be spread. Excess use of hand sanitizers makes our body more prone to certain infections [22, 23].

Therefore, we have to opt for some herbal alternatives, to sanitize hands in an utmost gentle manner. The natural ingredients used assure no side effects; one can apply them anytime, anywhere. Some common natural ingredients used are listed below-

- Aloe Vera: Aloe vera has hydrating and healing properties that reconstruct the skin and helps to retain moisture. It also helps in reducing fungal infection and skin allergies as it is a good anti-inflammatory agent. Its gel consists of antioxidants that act as skin protective [23]. It is rich in vitamins, minerals, sugars, salicylic and amino acids [24]. The main benefit of aloe vera is that it contains natural moisturizers that help to hydrate dry skin without leaving greasy residue. Aloe gel protects against damage caused to the skin by UV or other radiations. An antioxidant protein, metallothionein, scavenges hydroxyl radicals [25]. It prevents suppression of delayed-type hypersensitivity caused by UV radiation [26 - 28].

- Tea tree: It is antimicrobial with instant disinfecting properties. It leaves skin smooth and clean. It regulates the activity of sebaceous glands, thereby controlling sebum production. It is a gentle moisturizer, it best hydrates oily skin with soft mattifying effects on skin $[29,30]$. The anti-microbial activity of Tea Tree Oil is 11 times more than that of Phenol. The antiviral activity of its oil was first studied on tobacco mosaic virus and tobacco plants and was found to exert most of its antiviral activity on free virus [31,32]. It exhibits a broad-spectrum antimicrobial activity is mainly due to the presence of terpene as terpinen-4-ol [33].

- Evening primrose: Essential oil from the petals of Palma rosa is used for skin care [34]. It is well known for skin care in Ayurveda. Essential oils from the plant contain terpenoids, phenylpropanoids or benzenoids, fatty acid and amino acid derivatives. Essential oil of palmarosa exhibit potent antibacterial activity [35]. Linolenic acid rich oil of its seeds, as well as total phenolic and flavonoids contents, are responsible for its antioxidant and antimicrobial activity of extracts of evening primrose flowers. Acetone extract had the highest extraction yield, total phenol and flavonoids content also exhibit antioxidant activity [36].

- Glycerine: It is an emollient that softens and moisturizes the skin and decreases itching and flaking caused due to harsh chemicals. Glycerine increases hydrogen bonding and makes it difficult for ethanol to evaporate quickly. Therefore the minimal amount of it is required. The components of hand rubs or sanitizers are either bactericidal or bacteriostatic. Various phenolics, alcohols and quaternary ammonium compounds are important constituents of hand disinfection preparations [37 - 39].

- Vitamin E: It leaves hands feeling soft and refreshed, having both humectant and emollient properties, making skin softer and smoother. Vitamin $\mathrm{E}$ is an oilsoluble nutrient, heavier than water-soluble products. It restores moisture and is best for dry and damaged skin. Vitamin E may alleviate the dryness, itching, and flaking caused by eczema or atopic dermatitis [40, 41].

\section{MATERIALS AND METHODS}

All the above contents were mixed in the appropriate amounts to prepare the formulation.

\subsection{Evaluation of Herbal Hand Wash}

Prepared formulation was then evaluated on various bases as Physical parameters and KAP Questionnaire.

\subsection{Organoleptic Parameters}

Colour- pale green 
Odour- pleasant

Appearance- uniform consistency, non-sticky in nature

\subsection{Physical Parameters PH}

$\mathrm{pH}$ meter, after calibration was read for the result and noted.

\subsection{Viscosity}

Viscometer was used to measure the viscosity of hand wash. Measured amount of herbal hand sanitizer was taken into a beaker and the tip of Viscometer was immersed into the hand sanitizer and the viscosity was obtained $[42,43]$.

\subsection{Stability}

The stability studies were carried out at different temperature conditions like $40^{\circ} \mathrm{C}, 25^{\circ} \mathrm{C} \& 37^{\circ} \mathrm{C}$ for 1 week period.

\subsection{Colour}

The colour was inspected visually.

\subsection{Odour}

The odour was perceived by smelling the formulation.

\subsection{Foam Height}

$1 \mathrm{ml}$ of sanitizer was taken and mixed evenly in $50 \mathrm{ml}$ distilled water. $500 \mathrm{ml}$ stoppered measuring cylinder was used to transfer volume, later it was make up quantity sufficient to $100 \mathrm{ml}$ with water. 25 strokes were given and left till aqueous volume measured upto $100 \mathrm{ml}$ and the foam height was measured.

\subsection{Foam Retention}

$250 \mathrm{ml}$ graduated cylinder was filled with $50 \mathrm{ml}$ of the formulation and shaken 10 times. At 1-minute interval each for 4 minutes the volume of foam was noted. Persistent Foam retention should remain for at least 5 minutes.

\subsection{Skin Irritation}

The formulation was applied on skin and left for 30 minutes [44 - 47].

\subsection{Anti-microbial Activity}

Bacterial samples: Gram positive and Gram negative bacteria i.e. Staphylococcus aureus, Escherichia coli, Salmonella sp and Candida albicans, were collected from IMTEC Chandigarh, India. Bacterial suspension of concentration $10 \mathrm{CFU} / \mathrm{ml}$ was used. Media A. Nutrient broth and agar B. MacConkey agar C. Mueller Hinton Agar Methods Standardization of inoculums The inoculums prepared from the stock cultures, were maintained on nutrient agar at $4{ }^{\circ} \mathrm{C}$ and subcultured onto Nutrient broth using a sterile wire loop. Antimicrobial studies of herbal extract the screening of antimicrobial efficacy of the herbal extracts was performed on various microorganisms by using dip well method as per the standard procedure. Three sterile Petri plates were taken for testing the antimicrobial activity of herbal extracts against three different microorganisms i.e. Escherichia coli, Staphylococcus aureus, Salmonella and Candida albicans. The plates were filled with MacConkey and Muller Hinton agar solution and allowed for solidification. After solidification, the microorganisms from the subculture were inoculated into the nutrient agar media and three discs were inoculated with Azadirachta indica, Ocimum sanctum and Citrus limon extracts, respectively. The plates were incubated at $37^{\circ} \mathrm{C}$ overnight. After 24 hours of incubation, the plates were observed for the zone of inhibition. From the zone of inhibition the anti microbial activity of formulation is estimated as shown in Tables 1-3.

\subsection{Determination of Minimum Inhibitory Concentration (MIC) of the Extracts}

The MIC is defined as the lowest concentration that completely inhibits the growth of microorganisms for $24 \mathrm{hrs}$ incubation. Determination of minimum inhibitory concentration of extracts was determined by preparing different concentrations of extracts $200 \mu \mathrm{g}, 400 \mu \mathrm{g}$ and $800 \mu \mathrm{g}$ were added respectively to the nutrient broth (Tables 1-3). A $50 \mu$ l volume of each dilution was added aseptically into the wells of Mueller Hinton agar plates that were already seeded with the standardized inoculums of the test bacteria. All experiments were performed in triplicate. The agar plates were incubated at $37^{\circ} \mathrm{C}$ for 24 hours. The lowest concentration of extracts showing a clear zone of inhibition was considered as the MIC.

\subsection{Analysis by KAP Questionnaire}

Diabport Healthcare Pvt. Ltd. (Developed under Kalam Center for Innovation and Incubation of Startups) assessed general awareness on hand sanitization with respect to KAPs in participants. The study was conducted during the health camps organised by Diabport health care at various parks in Kanpur.

The study population was subjected to self-administrative structured questionnaire, which was developed by Diabport Healthcare Pvt. Ltd. and revised by two expert doctors in the field of derma care to enquire about KAP of hand hygiene. The questionnaire was composed of three parts:

Multiple choice questions for the assessment of KAP of hand sanitization [48] The scoring system was as follows:

- Knowledge Score: One point for each correct answer for 5 questions on knowledge considered $50 \%$ for correct answers of the total score. Not passed knowledge, if $<50 \%$, and passed, if $\geq 50 \%$.

- Attitude Score: A total of 7 questions have been given to people, and results were observed in terms of percentage agree or disagree.

- Practice Score: Practice score was calculated in percentage; one point for each positive answer out of 6 questions. Responses were Appropriate, if $\geq 75 \%$, and inappropriate if $<75 \%$.

\subsection{Ethical Considerations}

Our study was approved by the Institutional Ethical 
Committee of our Institute with reference number PSIT/20-21/IEC-12.

\section{RESULTS AND DISCUSSION}

The present work was carried out to prepare anti-microbial plant-based preparation. The formulation was prepared with natural components that are compatible with any similar hand sanitization. It was evaluated on organoleptic norms to ensure the quality of the product.

Green colour of the formulation was inspected visually. The odour of the formulation was pleasant.

The viscosity was carried out by Viscometer. The results of the observation are shown in Table 1. The viscosity of Formulation was found to be the best for herbal hand sanitization. $\mathrm{pH}$ meter was used to measure $\mathrm{pH}$, and was found to be 6.87 .

\subsection{Stability}

The study was carried out for 7 days and no change was noticed. The observations are listed in Tables $\mathbf{2}$ and $\mathbf{3}$.

Table 1. Organoleptic features and pH.

\begin{tabular}{|c|c|c|}
\hline Sr. No. & Parameter & Result \\
\hline 1 & Color & Pale-Green \\
\hline 2 & Odor & Lemon like \\
\hline 3 & Viscosity & 50 poise \\
\hline 4 & $\mathrm{pH}$ & 6.87 \\
\hline
\end{tabular}

Table 2. Measurement of stability.

\begin{tabular}{|c|c|}
\hline S.No. & Appearance \\
\hline 1. & No Change \\
\hline
\end{tabular}

Table 3. Foam features \& skin irritation.

\begin{tabular}{|c|c|c|c|}
\hline S.No. & Foam Height & Foam Retention & Skin Irritation \\
\hline 1. & $25 \mathrm{ml}$ & Stable & Nil \\
\hline
\end{tabular}

3.2. Antimicrobial Studies of Herbal Hand Wash Gel
The screening of antimicrobial efficacy of the formulated polyherbal hand wash gel was aseptically performed on Escherichia coli, Staphylococcus aureus, and Salmonella by using Dip well Agar Diffusion Technique described by Bauer et al., and demonstrated by Cakir et al., was employed for antibacterial bioassay. A well was prepared in the plates (containing $15 \mathrm{ml}$ of Muller Hinton agar medium) with the help of a cork-borer $(0.85 \mathrm{~cm}) \cdot 100 \mu \mathrm{l}$ of the test compound (herbal hand wash gel) was introduced into the well. The standard antibiotic discs like erythromycin, penicillin, streptomycin and ampicillin were used as a standard. The plates were incubated overnight at $37^{\circ} \mathrm{C}$. Efficiency of hand wash gel was determined by measuring the diameter of zone of inhibition at $200 \mu \mathrm{g} \mathrm{ml}-1$, $400 \mu \mathrm{gml}-1$ and $800 \mu \mathrm{gml}-1$ concentration. (Table 4 and Fig. 1)
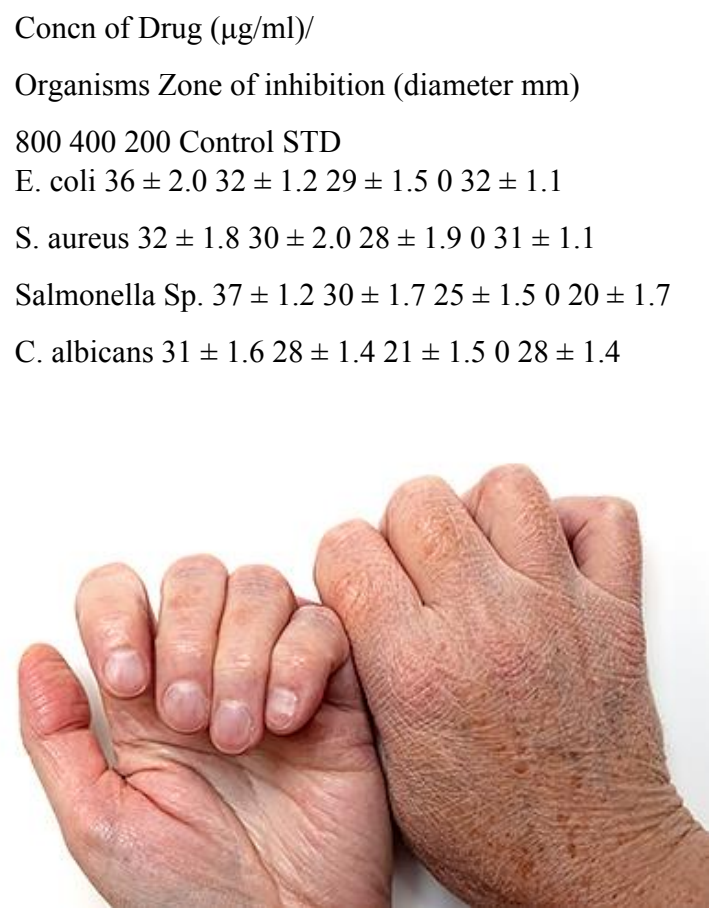

Fig. 1. Rough hands with chemical sanitizers.

Table 4. Questionnaire for patient's knowledge score in percentage.

\begin{tabular}{|c|c|c|c|}
\hline S.No & Knowledge & Positive Response (\%) & Negative Response (\%) \\
\hline $\mathbf{1 .}$ & What is sanitization? & 55 & 45 \\
\hline $\mathbf{2 .}$ & Do you know constantly elevated glucose levels can lead to dermal complications? & 14 & 86 \\
\hline $\mathbf{3 .}$ & Do you know other complications of unhygien? & 56 & 44 \\
\hline $\mathbf{4 .}$ & Do you know the relation between hygiene and infection? & 45 & 55 \\
\hline $\mathbf{5 .}$ & How infections can be prevented? & 42 & 58 \\
\hline & Total percentage & $\mathbf{4 2 . 4}$ & $\mathbf{5 7 . 6}$ \\
\hline
\end{tabular}


Table 5. Questionnaire for patient's attitude toward Hygiene in percentage.

\begin{tabular}{|c|c|c|c|}
\hline S.No & Attitude & Agree (\%) & Not Agree (\%) \\
\hline 1. & Do you know post complications of frequent hand sanitization? & 36 & 74 \\
\hline $\mathbf{2 .}$ & Are your symptoms get worsen in winters? & 52 & 48 \\
\hline $\mathbf{3 .}$ & Do you know dry skin is caused by excessive use of sanitizers? & 56 & 44 \\
\hline $\mathbf{4 .}$ & Do you know that proper moisturization can prevent hand dryness from occurring? & 54 & 46 \\
\hline $\mathbf{5 .}$ & Do you know hand ulcers (open sores) are caused by poor medical care? & 34 & 66 \\
\hline $\mathbf{6 .}$ & Do you know dry skin on the hand can cause atopic dermatitis? & 43 & 57 \\
\hline 7. & Has your doctor ever told you that dry skin can lead to eczema? & 35 & $\mathbf{4 4 . 2}$ \\
\hline & Total percentage & $\mathbf{4 4 . 2}$ \\
\hline
\end{tabular}

Table 6. Questionnaire for patient's hygiene practice in percentage.

\begin{tabular}{|c|c|c|c|}
\hline S.No & Practice & Appropriate (\%) & Inappropriate (\%) \\
\hline 1. & Are you performing proper hand care? & 45 & 55 \\
\hline 2. & Daily washing the hands? & 64 & 36 \\
\hline 3. & Keep the skin of hands soft to prevent dryness? & 45 & 55 \\
\hline 4. & Warning signs for which consultation is required? & 37 & 73 \\
\hline 5. & Drying the hands after washing? & 34 & 66 \\
\hline \multirow[t]{2}{*}{6.} & Trim hand nails straight with care? & 42 & 58 \\
\hline & Total percentage & 44.5 & 57.1 \\
\hline
\end{tabular}

Table 7. Feedback on herbal Sanitizer designed.

\begin{tabular}{|c|c|c|c|}
\hline S.No & Issue & Yes $(\%)$ & $\begin{array}{c}\text { No } \\
(\%)\end{array}$ \\
\hline 1. & Is the sanitizer smelling good? & 81 & 19 \\
\hline 2. & Is the sanitizer sticky? & 15 & 85 \\
\hline 3. & Does it possess uniform spreadability? & 80 & 20 \\
\hline 4. & Does it absorb well? & 78 & 22 \\
\hline 5. & Does it cause any form of skin irritation as rashes, itching or swelling? & 16 & 84 \\
\hline 6. & Does it soften the skin? & 82 & 18 \\
\hline
\end{tabular}

\section{DISCUSSION}

The formulation prepared was found to be apt as per the considerations of physical parameters, stability criteria, since made with the combination of herbs, makes it skin friendly. The zone of inhibition was formed resulting from the herbal hand wash gel against different bacterial isolates, showed that the hand wash prepared with Azadirachta indica, Ocimum sanctum and Citrus limon extracts had great activity. Statistical analysis findings in Fig 6 showed that herbal hand wash gel is the broad spectrum antibacterial agent with different responses for different bacterial kinds tested. From the investigation, it was clear that Azadirachta indica, Ocimum sanctum and Citrus limon were equally effective against both groups of bacteria. Azadirachita indica produced the widest zone of inhibition against E.coli with a diameter of $3.2 \mathrm{~cm}$, S.aureus $2.8 \mathrm{~cm}$, Salmonella $2.4 \mathrm{~cm}$ followed by C.albicans $2.6 \mathrm{~cm}$. Ocimum sanctum produced the widest zone of inhibition against E.coli with diameter of $2.8 \mathrm{~cm}$, S.aureus $2.5 \mathrm{~cm}$, Salmonella $2.0 \mathrm{~cm}$ followed by C.albicans $2.8 \mathrm{~cm}$. Citrus limon produced the widest zone of inhibition against with diameter of C.albicans $3.6 \mathrm{~cm}$, S.aureus $3.4 \mathrm{~cm}$, Salmonella $3.2 \mathrm{~cm}$ followed by E.coli $3.0 \mathrm{~cm}$. Formulated hand sanitizer produced the widest zone of inhibition against Salmonella $3.7 \mathrm{~cm}$ E.coli with diameter of $3.6 \mathrm{~cm}$, S.aureus $3.2 \mathrm{~cm}$, followed by C.albicans $3.1 \mathrm{~cm}$. On the basis of the questionnaire made, participants were found to be optimum with respect to knowledge. As much awareness is required to be circulated among people regarding complications, infections caused due to improper sanitization. Unhygienic conditions can also enhance diabetic dermopathy and other issues of skin. The study suggested that participants with attitude as shown in Table $\mathbf{5}$ towards sanitization can help prevent infections in individuals significantly more than having knowledge of Sanitization as shown in Table 4. Thus, it can be concluded that participants with good sanitization practice can help eradicate post effects in individuals significantly more than knowledge of same in individuals when $42 \%$ of participants had good knowledge of sanitization. Similarly, the attitude of participants for being aware of damage caused on skin by excessive use of sanitizer, proper moisturization can prevent hand dryness and hand ulcers, and atopic dermatitis caused by poor medical care. It has been concluded that there is a difference in knowledge and attitude towards sanitization in the study population, while practice towards it was found to be similar in participants. Patient's hygiene practices were found 
to be less as in Table 6 was appropriate in terms of consideration of proper hand care, daily washing and drying the hands, trimming hand nails. Application of herbal sanitizer showed no adverse effects in the present study, which indicated the safety of this formulation. Active ingredients present in this herbal formulation are known to possess anti-microbial and antiseptic actions, which aid in alleviating the increased infection due to improper sanitization. The formulation was found to be good smelling, non-sticky, with uniform spreadability, it gets easily absorbed by the skin, leaving it well moisturized and irritation-free, as also confirmed with feedback form as shown in Table 7.

\section{CONCLUSION}

Hands are the most common pathogen transfer means to people and proper hand hygiene can prevent infections and the spread of antimicrobial resistance. Use of alcohol-based hand sanitizers is the need of the present scenario. It may be concluded from the above observations that Herbal based Hand Sanitizer has significant anti-microbial effects on many microbes. With the prevailing pandemic situation, it has become an urgent need to use sanitizer at regular intervals by everyone, keeping in view the hazards exerted by chemical based sanitizers, we can opt for a sanitizer based on herbs, as produced by Diabport Pvt Ltd with multiple benefits.

\section{FUTURE PROSPECTS}

With current lifestyle and growing health issues, owing to the scenario of viral infections, there has been a constant need for prompt protection against all types of germs. At the current time, with the outbreak of COVID-19, the hand sanitizer market is in the thriving era, which had inculcated a sense of awareness for keeping ourselves sanitized. There has been the presence of hand sanitizer products in the market since long, still, Indian consumers are not using hand sanitizer on a regular basis. The use of plant-based sanitizer has become mandatory to keep ourselves protected.

\section{ETHICS APPROVAL AND CONSENT TO PARTICIPATE}

This study was approved by the Institutional Ethical Committee of Pranveer Singh Institute of Technology, Kanpur, U.P, India with approval number PSIT/20-21/IEC-12.

\section{HUMAN AND ANIMAL RIGHTS}

No Animals were used in this research. All human research procedures were followed in accordance with the ethical standards of the committee responsible for human experimentation (institutional and national), and with the Helsinki Declaration of 1975, as revised in 2013.

\section{CONSENT FOR PUBLICTION}

Informed consent was obtained from all the participants.

\section{AVAILABILITY OF DATA AND MATERIALS}

The data that support the findings of this study are available within the article.

\section{FUNDING}

None.

\section{CONFLICT OF INTEREST}

The authors declare no conflict of interest, financial or otherwise.

\section{ACKNOWLEDGEMENETS}

Declared none.

\section{REFERENCES}

[1] Berardi A, Perinelli DR, Merchant HA, et al. Hand sanitisers amid CoViD-19: A critical review of alcohol-based products on the market and formulation approaches to respond to increasing demand. Int $\mathrm{J}$ Pharm 2020; 584119431

[http://dx.doi.org/10.1016/j.ijpharm.2020.119431] [PMID: 32461194]

[2] Pickering AJ, Boehm AB, Mwanjali M, Davis J. Efficacy of waterless hand hygiene compared with handwashing with soap: A field study in Dar es Salaam, Tanzania. Am J Trop Med Hyg 2010; 82(2): 270-8. [http://dx.doi.org/10.4269/ajtmh.2010.09-0220] [PMID: 20134005]

[3] Curtis V, Cairncross S. Effect of washing hands with soap on diarrhoea risk in the community: A systematic review. Lancet Infect Dis 2003; 3(5): 275-81.

[http://dx.doi.org/10.1016/S1473-3099(03)00606-6]

[PMID: 12726975]

[4] Pratt RJ, Pellowe C, Loveday HP, et al. The epic project: developing national evidence-based guidelines for preventing healthcare associated infections. Phase I: Guidelines for preventing hospitalacquired infections. J Hosp Infect 2001; 47(Suppl.): S3-S82. [http://dx.doi.org/10.1053/jhin.2000.0886] [PMID: 11161888]

[5] Mondal S, Kolhapure SA. Evaluation of the antimicrobial efficacy and safety of pure hands herbal hand sanitizer in hand hygiene and on inanimate objects. Antiseptic 2004; 101: 55-7.

[6] Tambekar DH, Shirsat SD, Suradkar SB, Rajankar PN, Banginwar YS. Prevention of transmission of infectious disease: Studies on hand hygiene in health-care among students. Cont J Biomed Sci 2007; 1: 6-10.

[7] Lauharanta J, Ojajärvi J, Sarna S, Mäkelä P. Prevention of dryness and eczema of the hands of hospital staff by emulsion cleansing instead of washing with soap. J Hosp Infect 1991; 17(3): 207-15. [http://dx.doi.org/10.1016/0195-6701(91)90232-W] [PMID: 1675649]

[8] Borgatta L, Fisher M, Robbins N. Hand-washing, germicides and gloves, Woman \& Health. Hand protection and protection from hands 1989; 15(4): 77-92.

[9] Kolhapure SA, Sunanda M. Evaluation of the antimicrobial efficacy and safety of Pure Hands herbal hand herbal hand wash gel in hand hygiene and on inanimate objects. Antiseptic 2004; 101(2): 55-7.

[10] Larson EL, Hughes CA, Pyrek JD, Sparks SM, Cagatay EU, Bartkus JM. Changes in bacterial flora associated with skin damage on hands of health care personnel. Am J Infect Control 1998; 26(5): 513-21. [http://dx.doi.org/10.1016/S0196-6553(98)70025-2] [PMID: 9795681]

[11] Winnefeld M, Richard MA, Drancourt M, Grob JJ. Skin tolerance and effectiveness of two hand decontamination procedures in everyday hospital use. Br J Dermatol 2000; 143(3): 546-50.

[http://dx.doi.org/10.1111/j.1365-2133.2000.03708.x] [PMID: 10971327]

[12] Reynolds SA, Levy F, Walker ES. Hand sanitizer alert. Emerg Infect Dis 2006 ; $12(3)$ : $527-9$.

[http://dx.doi.org/10.3201/eid1203.050955] [PMID: 16710985]

[13] Cheesbrough M. District laboratory practice in tropical countries. 2nd ed. New York: Cambridge University Press 2006; p. 137. [http://dx.doi.org/10.1017/CBO9780511543470]

[14] Valgas C, De Souza SM, Smania EF, Smania A. Screening methods to determine antibacterial activity of natural products. Braz J Microbiol 2007; 38: 369-80.

[http://dx.doi.org/10.1590/S1517-83822007000200034]

[15] Vandepitte J, Verhaegen J, Engbaek K, Rohner P, Piot P, Heuck CC. Basic laboratory procedures in clinical bacteriology. 2nd ed. Geneva: WHO 2003.

[16] Pittet D, Allegranzi B, Boyce J. The World Health Organization guidelines on hand hygiene in health care and their consensus recommendations. Infect Control Hosp Epidemiol 2009; 30(7): 
611-22.

[http://dx.doi.org/10.1086/600379] [PMID: 19508124]

[17] Hilburn J, Hammond BS, Fendler EJ, Groziak PA. Use of alcohol hand sanitizer as an infection control strategy in an acute care facility. Am J Infect Control 2003; 31(2): 109-16.

[http://dx.doi.org/10.1067/mic.2003.15] [PMID: 12665745]

[18] Daniels SM. Maintaining healthy hands. J Contin Educ Nurs 2010; 41(1): 14-5.

[http://dx.doi.org/10.3928/00220124-20091222-03] [PMID: 20102136]

[19] Golin AP, Choi D, Ghahary A. Hand sanitizers: A review of ingredients, mechanisms of action, modes of delivery, and efficacy against coronaviruses. Am J Infect Control 2020; 48(9): 1062-7. [http://dx.doi.org/10.1016/j.ajic.2020.06.182] [PMID: 32565272]

[20] Hammond B, Ali Y, Fendler E, Dolan M, Donovan S. Effect of hand sanitizer use on elementary school absenteeism. Am J Infect Control 2000; 28(5): 340-6.

[http://dx.doi.org/10.1067/mic.2000.107276] [PMID: 11029132]

[21] Simon AC. Hand hygiene, the crusade of the infection control specialist. Alcohol-based handrub: The solution! Acta Clin Belg 2004; 59(4): 189-93

[http://dx.doi.org/10.1179/acb.2004.028] [PMID: 15597725]

[22] Vessey JA, Sherwood JJ, Warner D, Clark D. Comparing hand washing to hand sanitizers in reducing elementary school students' absenteeism. Pediatr Nurs 2007; 33(4): 368-72.

[PMID: 17907739]

[23] Atherton P. Aloe vera revisited. Br J Phytother 1998; 4: 76-83.

[24] Shelton RM. Aloe vera. Its chemical and therapeutic properties. Int J Dermatol 1991; 30(10): 679-83.

[http://dx.doi.org/10.1111/j.1365-4362.1991.tb02607.x] [PMID: 1823544]

[25] Byeon SW, Pelley RP, Ullrich SE, Waller TA, Bucana CD, Strickland FM. Aloe barbadensis extracts reduce the production of interleukin-10 after exposure to ultraviolet radiation. J Invest Dermatol 1998; 110(5): $811-7$.

[http://dx.doi.org/10.1046/j.1523-1747.1998.00181.x] [PMID: 9579551]

[26] Peng SY, Norman J, Curtin G, Corrier D, McDaniel HR, Busbee D. Decreased mortality of Norman murine sarcoma in mice treated with the immunomodulator, Acemannan. Mol Biother 1991; 3(2): 79-87. [PMID: 1910624]

[27] 't Hart LA, Nibbering PH, van den Barselaar MT, van Dijk H, van den Berg AJ, Labadie RP. Effects of low molecular constituents from Aloe vera gel on oxidative metabolism and cytotoxic and bactericidal activities of human neutrophils. Int J Immunopharmacol 1990; 12(4): 427-34.

[http://dx.doi.org/10.1016/0192-0561(90)90026-J] [PMID: 2167880]

[28] Rasmussen JE. Diet and acne. Int J Dermatol 1977; 16(6): 488-92. [http://dx.doi.org/10.1111/j.1365-4362.1977.tb01861.x] [PMID: 142748]

[29] Smith RN, Braue A, Varigos GA, Mann NJ. The effect of a low glycemic load diet on acne vulgaris and the fatty acid composition of skin surface triglycerides. J Dermatol Sci 2008; 50(1): 41-52. [http://dx.doi.org/10.1016/j.jdermsci.2007.11.005] [PMID: 18178063]

[30] Southwell IA, Hayes AJ, Markham JL, Leach DN. The search for optimally bioactive Australian tea tree oil. Acta Hortic 1993; (334): 265-75.

[http://dx.doi.org/10.17660/ActaHortic.1993.344.30]
[31] Mason DJ, Dybowski R, Larrick JW, Gant VA. Antimicrobial action of rabbit leukocyte CAP18106-137. Antimicrob Agents Chemother 1997; 41: 624-9.

[http://dx.doi.org/10.1128/AAC.41.3.624] [PMID: 9056004]

[32] Beylier MF. Bacteriostatic activity of some Australian essential oils. Perfum Flavor 1979; 4: 23-5.

[33] Sharma N, Tripathi A. Fungitoxicity of the essential oil of Citrus sinensis on post-harvest pathogens. World J Microbiol Biotechnol 2006; 22: 587-93.

[http://dx.doi.org/10.1007/s11274-005-9075-3]

[34] Rastogi RP, Mehrotra BN. Central Drug Research Institute and Publications \& Information Directorate, New Delhi. 1990.

[35] Hammer KA, Carson CF, Riley TV. Antifungal activity of the components of Melaleuca alternifolia (tea tree) oil. J Appl Microbiol 2003; 95(4): 853-60

[http://dx.doi.org/10.1046/j.1365-2672.2003.02059.x] [PMID: 12969301]

[36] McDonald LC. Hand hygiene in the new millennium: Drawing the distinction between efficacy and effectiveness. Infect Control Hosp Epidemiol 2003; 24(3): 157-9.

[http://dx.doi.org/10.1086/502183] [PMID: 12683504]

[37] David OM, Ayeni D, Fakayode IB, Famurewa O. Evaluation of antibacterial properties of various hand sanitizers wipes used for cosmetic and hand hygiene purposes in Nigeria. Microbiol Res Int 2013; 1(2): 22-6.

[38] Russell AD. Factors influencing the efficacy of germicides.Disinfection, sterilization and antisepsis: Principles, practices, challenges, and new research. Washington, DC: Association for professionals in infection control and epidemiology 2004; pp. 162-70.

[39] Ulrich JA. Techniques of skin sampling for microbial contaminants. J Investigat Microbiol 1965; 4(3): 121-3.

[40] Das K, Tiwari RKS, Shrivastava DK. Techniques for evaluation of medicinal plant products as antimicrobial agent: Current methods and future trends. Faslnamah-i Giyahan-i Daruyi 2010; 4(2): 104-11.

[41] Samhita S. Madhyama khanda, 2/1, Hindi translation Dr. 4th ed. Varanasi: Shailaja Srivastava, Chaukhambha Orientalia 2005.

[42] Minakshi G, Joshi DV Kamat, Kamat SD. Evaluation of herbal handwash formulation. Nat Prod Radiance 2008; 7(5): 413-5.

[43] Narkhede DB. Formulation and evaluation of coconut oil liquid soap. Int J Pharma World Res 2010; 2(3): 1-15.

[44] Sharp K, Haysom I, Parkinson R. Antimicrobial hand washes for domestic use - their effectiveness in vitro and in normal use. Int $\mathrm{J}$ Consum Stud 2001; 25(3): 200-7.

[http://dx.doi.org/10.1046/j.1470-6431.2001.00166.x]

[45] Dharmishtha M, Falguni G. Antibacterial activity of methanolic fruit extract of randia dumetorum lamk. Int J Pharm Tech Res 2009; 1(3): 679-81.

[46] Mahl MC. New method for determination of efficacy of health care personnel hand wash products. J Clin Microbiol 1989; 27(10): 2295-9. [http://dx.doi.org/10.1128/jcm.27.10.2295-2299.1989] [PMID: 2685028]

[47] interventional study of knowledge, attitude and practice (KAP) towards tuberculosis among patients with koch's disease. Int J Pharm Pharm Sci 2016; 8: 58-61.

[48] Gholap MC, Mohite VR. To assess the knowledge and practice regarding foot care among Diabetes patients at Krishna hospital, Karad. Indian J Soc Res 2013; 4: 69-75.

\section{(c) 2021 Wal et al.}

This is an open access article distributed under the terms of the Creative Commons Attribution 4.0 International Public License (CC-BY 4.0), a copy of which is available at: https://creativecommons.org/licenses/by/4.0/legalcode. This license permits unrestricted use, distribution, and reproduction in any medium, provided the original author and source are credited. 